\title{
Implementasi Skema Collocated Semi-implicit untuk SWE-Exner menggunakan Fluks HLLE
}

\author{
A. Utomo ${ }^{\# 1}$, P. H. Gunawan ${ }^{* 2}$ \\ \# School of Computing, Telkom University, Jalan Telekomunikasi No. 1 Terusan Buah Batu, Bandung \\ 40257, Indonesia. \\ 1 ardhitoutm@student.telkomuniversity.ac.id \\ ${ }^{2}$ phgunawan@telkomuniversity.ac.id
}

\begin{abstract}
The shallow water - Exner equation is given to simulate a movement of underwater sediment. This journal explains that merging two solution of shallow water equation (SWE) and Exner equation is possible to be done. This is known as splitting technique, which is, after the solution of SWE using numerical flux is found, the Exner equation is solved by semi-implicit technique. Here, for fluid motion, the Harten-Lax-van Leer and Einfeld (HLLE) numerical flux is used. This journal describes the steps in simulating the shallow water-Exner equation: finding the solution of SWE, Exner, numerical flux, and friction of the simulation. After that, some problems are elaborated to show the result of the simulation. The results show that, by comparing the results, the simulations are in a good agreement with other results in other journals.
\end{abstract}

Keywords: shallow water equations, Exner, friction, splitting, HLLE, semi-implicit, approximation.

\begin{abstract}
Abstrak
Pada jurnal ini simulasi persamaan Air Dangkal - Exner untuk memodelkan pergerakan sedimen di bawah aliran air dangkal dilakukan. Jurnal ini menjabarkan bahwa penggabungan persaamaan antara Air Dangkal dan Exner dapat dilakukan menggunakan teknik splitting, yaitu setelah ditemukannya solusi dari persamaan Air Dangkal menggunakan fluks numerik, persamaan Exner dicari secara semi-implisit. Fluks numerik Harten-Lax-van Leer and Einfeld (HLLE) digunakan. Jurnal ini menjelaskan langkah-langkah dalam pembentukkan simulasi persamaan Air Dangkal - Exner: pencarian solusi dari persamaan Air Dangkal, Exner, nilai fluks, dan juga penggunaan friksi pada simulasi. Setelah itu, diselesaikan beberapa kasus untuk membuktikan hasil simulasi. Dari hasil simulasi dapat dilihat bahwa simulasi menghasilkan bentuk yang sesuai dengan jurnal yang dibandingkan.
\end{abstract}

Kata Kunci: Persamaan air dangkal, Exner, friksi, splitting, HLLE, semi-implisit, rata-rata.

\section{Pendahuluan}

$\mathbf{P}$ ARTIKEL-PARTIKEL yang berada di dasar air mengalir terbuat dari banyak materi. Partikel-partikel tersebut akan bergerak mengikuti arah aliran air, dan biasanya dibagi menjadi tiga bagian: bed-load, saltasi, dan suspensi (lihat Gambar 1) [12]. Jurnal ini memfokuskan pada pergerakan bed-load pada aliran air. Simulasi pergerakan bed-load dapat dibentuk menggunakan persamaan air dangkal atau shallow water equations ( $S W E$ ) untuk memodelkan pergerakan air dan persamaan Exner atau Exner equation untuk memodelkan pergerakan pada partikel di dasar air.

Shallow water equations atau SWE adalah sistem hiperbolik dalam hukum konservasi yang menjelaskan tentang bermacam-macam aliran geofisikal seperti sungai, area pesisir, lautan, atmosfir, atau longsor bila 


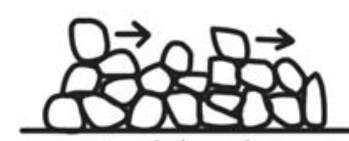

Bed-load

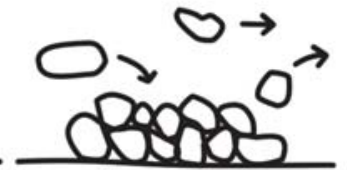
Suspensi

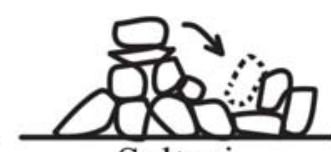

Saltasi

Gambar 1: Bed-load didefinisikan sebagai jenis perpindahan yang kumpulan sedimennya bergerak di dasar. Suspensi merupakan kejadian di mana sedimen mendapatkan fluks yang besar yang mengakibatkan partikel-partikel tersebut mudah bergerak bersama aliran. Sedangkan saltasi didefinisikan sebagai jenis perpindahan yang tiap partikelnya melompat tergantung dari diameternya.

dilengkapi dengan terminologi tertentu. Topografi ataupun friksi memungkinkan untuk diikutsertakan tergantung kebutuhan [3]. Untuk dapat menggunakan SWE, skala vertikal atau kedalaman air harus berukuran lebih kecil dari 1/20 tipe skala horizontal atau panjang gelombangnya, atau dapat ditulis $\lambda \geq 20 h[17]$.

Persamaan Exner merupakan persamaan konservasi massa pada sedimen yang menghasilkan interaksi dengan bergeraknya fluida [15]. Gambar 2 merupakan gambaran kasar satu dimensi pergerakan bedload. Variabel $h$ merupakan tinggi air, $H$ adalah kedalaman kontur tetap dari tinggi referensi, $u$ adalah kecepatan aliran air pada arah $x$, dan $z$ merupakan tinggi sedimen dari kontur tetap.

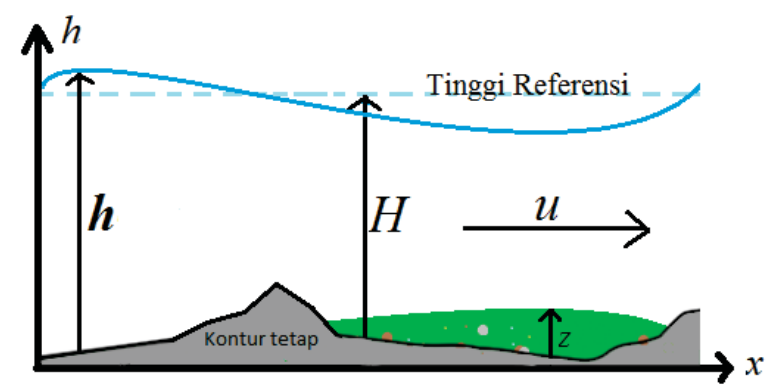

Gambar 2: Sketsa satu dimensi SWE dengan dasar bersedimen.

Persamaan SWE - Exner terdiri dari tiga persamaan: konservasi massa, konservasi momentum, dan Exner. Beberapa model SWE - Exner sudah didemonstrasikan: [14] dan [15]. Skema pada [15] merupakan hydrostatic relaxation scheme, dengan cara kerja yaitu ketiga persamaan $S W E$ - Exner direlaksasi untuk mendapatkan lima buah nilai eigen, yang kelima nilai eigen tersebut digunakan sebagai fluks numerik. Ketiga persamaan dihitung pada saat yang bersamaan menggunakan bantuan dari fluks numerik, dan nilai yang dihasilkan digunakan untuk mencari nilai $u$ yang akan digunakan untuk timestep berikutnya. Sedangkan skema staggered pada [14] memiliki cara kerja dengan mencari terlebih dahulu persamaan konservasi massa dan konservasi momentum. Nilai yang dihasilkan lalu digunakan untuk mencari nilai dari persamaan Exner. Hal ini berarti metode dalam pencarian Exner menggunakan semi-implicit. Selain itu skema staggered ini tidak menggunakan fluks numerik dalam pencarian ketiga persamaan.

Pada skema relaksasi hidrostatis di [15], ketiga persamaan langsung digabung dan dihitung secara bersamaan, jadi dapat langsung terbentuk solusi riemann solvernya, sedangkan jurnal ini menggunakan teknik splitting seperti pada skema staggered di [14], namun selain menggunakan fluks numerik, nilai dari $u$ yang digunakan pada pencarian solusi exner menggunakan $u$ rata-rata. Cara kerja splitting yaitu pertama-tama dilakukan pencarian solusi SWE menggunakan HLLE, lalu dicari solusi dari persamaan Exner secara semi-implicit. Karena solusi SWE menghasilkan $u_{i}^{n+1}$ sedangkan solusi persamaan Exner $z_{i}^{n+1}$ memerlukan $u_{i+\frac{1}{2}}$ dan $u_{i-\frac{1}{2}}$, maka suatu cara perlu dilakukan untuk menemukan kedua nilai tersebut. Jurnal ini akan menunjukkan bahwa penggunaan rata-rata dalam pencarian kedua nilai tersebut dapat dilakukan dan menghasilkan kesesuaian setelah dibentuk simulasinya, dibandingkan dengan jurnal- 
jurnal lain (skema collocated dari [14], literatur mengenai bendungan runtuh pada dasar datar dari [2]), dan diperiksa konvergensinya, yang dapat dilihat pada Bagian IV.

\section{SWE - Exner Model}

\section{A. Shallow Water Equation}

SWE terdiri dari dua persamaan: (1) persamaan kontinuitas yang diperoleh dari penurunan hukum konservasi massa, dan (2) persamaan momentum yang diperoleh dari penurunan hukum konservasi momentum. Persamaan tersebut dapat dijabarkan sebagai,

$$
\begin{gathered}
\partial_{t} h+\partial_{x}(h u)=0, \\
\partial_{t} h u+\partial_{x}\left(h u^{2}+\frac{1}{2} g h^{2}\right)=-g h \partial_{x}(z-H)-g h S_{f},
\end{gathered}
$$

dengan variabel $h$ merupakan kedalaman air, $g$ merupakan percepatan gravitasi, $u$ merupakan kecepatan fluida dari arah $x, S_{f}$ merupakan kemiringan gesekan atau friction slope [10], [15], dan $\partial z / \partial x$ merupakan ketebalan lapisan sedimen yang dapat dimodifikasi tergantung dari fluida dan percepatan gravitasi [4] di mana $z$ merupakan tinggi sedimen dari kontur tetap dan $H$ adalah kedalaman kontur tetap dari tinggi referensi [15] (lihat Gambar 2).

Pada jurnal ini, SWE diaplikasikan menggunakan finite volume method, maka sistem konservatif (atau bisa juga disebut hukum sistem konservasi [6]) digunakan. Persamaannya adalah,

$$
\partial_{t} U+\partial_{x}(F(U))=0
$$

dengan $U, F(U)$ digunakan $S W E$ (1), dan (2) [5]. Maka penjabarannya yaitu,

$$
U=\left(\begin{array}{c}
h \\
h u
\end{array}\right), F(U)=\left(\begin{array}{c}
h u \\
h u^{2}+\frac{1}{2} g h^{2}
\end{array}\right),
$$

Sistem konservatif akan digunakan pada diskritisasi pada Bagian III.

\section{B. Exner Equation}

Sedangkan untuk pergerakan sedimen di bawah aliran air digunakan persamaan Exner. Persamaan Exner menyatakan bahwa tingkat perubahan dari elevasi sedimen dasar sungai $z$ dapat dihubungkan ke kecepatan air $u$ [9]. Persamaan ini juga menjelaskan tentang keseimbangan massa dari sedimen dengan menyatakan bahwa tingkat lokal dari perubahan kenaikan sedimen berhubungan dengan gradien spasial dari pelepasan zat padat [1].

Persamaan Exner,

$$
\Phi \partial_{t} z+\partial_{x} Q_{s}=0
$$

dengan $\Phi=(1-\phi)$. $\phi$ merupakan besaran porositas (ukuran dari ruang kosong di antara material) dasar air, dan $Q_{s}$ adalah bed-load. Pencarian nilai $Q_{s}$ digunakan grass formula dengan persamaannya adalah,

$$
Q_{s}=A_{g}(u)|u|^{m-1} u
$$

dengan nilai $u$ yang digunakan sama seperti pada Bagian II-A, $m$ merupakan parameter yang diberikan kepada sedimen dengan nilai $1 \leq m \leq 4$. Nilai $m=3$ merupakan nilai yang biasa digunakan untuk variabel $m$ [15]. Lalu $A_{g}$ adalah nilai interaksi antara sedimen dengan air, yang nilainya $0 \leq A_{g} \leq 1$. Semakin tinggi nilai $A_{g}$, maka akan semakin kuat interaksi antara sedimen dengan fluida. 
A. Utomo et.AL.

Implementasi Skema Collocated...

\section{Friction Force}

Friction force atau gaya friksi merupakan sebuah persamaan yang berkerja sebagai peredam aliran air atau pemecah ombak yang datang dari suatu tempat ke tempat lain, dan penggunaannya memengaruhi simulasi yang terbentuk. Dengan adanya friksi, maka pergerakan air pada suatu titik akan berangsur-angsur meredam. Penggunaan ini diperkenalkan di [7] dan pengaplikasiannya dapat dilihat di [11]. Salah satu contoh nyata dari friksi adalah peredaman ombak laut yang datang ke pantai melalui hutan mangrove terlebih dahulu [13]. Persamaan friksi mempertimbangkan lereng friksi yang tergantung dari kondisi aliran [16], [18]. Dengan begitu, bila aliran berlapis, Manning cocok untuk digunakan [7], sedangkan Darcy-Weisbach cocok digunakan jika aliran bersifat turbulen [8].

Dikarenakan pemodelan yang ingin dilakukan merupakan pemodelan aliran fluida yang bersifat turbulen, maka digunakan persamaan Darcy-Weisbach. Persamaannya adalah adalah sebagai berikut.

$$
S_{f}=C_{f} \frac{|u| u}{8 g h}
$$

dengan $C_{f}$ adalah faktor friksi dari Darcy-Weisbach yang dipengaruhi oleh angka Reynold [13], [15]. Koefisien $C_{f}$ bersifat konstan. Nilai $u$ pada Persamaan (7) menggunakan $u$ yang sama seperti pada Bagian II-A.

\section{SKEMA NUMERIK SWE - Exner}

Pada bagian ini akan disatukan tiap-tiap bagian yang dijabarkan pada Bagian II. Pertama-tama friksi dicari terlebih dahulu, lalu nilai dari friksi digunakan untuk mencari fluks numerik. Fluks numerik digunakan untuk menemukan solusi dari SWE. Hasil dari kedua persamaan konservasi massa dan momentum $S W E$ akan diperbaharui $\left(h_{i}^{n+1}\right.$ dan $(h u)_{i}^{n+1}$, dari kedua nilai tersebut didapatkan $\left.u_{i}^{n+1}\right)$, lalu nilai $u_{i}^{n+1}$ akan diproses guna mendapatkan $u_{i \pm \frac{1}{2}}^{n+1}$ yang digunakan dalam pencarian solusi persamaan Exner. Setelah itu, nilai $z_{i}^{n+1}$ dari persamaan Exner diperbaharui dan perulangan kembali dilakukan untuk timestep berikutnya.

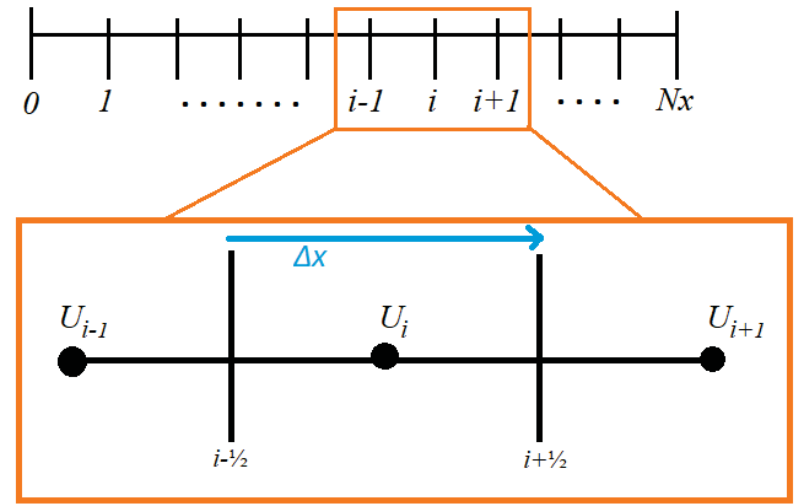

Gambar 3: Stensil Eksplisit 1D. Nilai $\Delta x$ dihitung dari pengurangan antara $+\frac{1}{2}$ dan $-\frac{1}{2}$.

Pertama-tama ditentukan panjang spasial pada kisi dengan mengurangi nilai sebelum dan setelahnya $\left(x_{+\frac{1}{2}}\right.$ dan $\left.x_{-\frac{1}{2}}\right)$ yang dapat juga dilihat pada Gambar 3. Maka persamaannya adalah,

$$
\Delta x_{i}=x_{i+\frac{1}{2}}-x_{i-\frac{1}{2}} \geq 0 .
$$

Setelah itu, ditentukan juga nilai diskrit dari waktu $t^{n}=n \Delta t . n$ merupakan bilangan asli dan $\Delta t \geq 0$. 
Dengan menggunakan skema konservatif yang sudah dijelaskan di II-A, maka skema dapat ditulis menjadi,

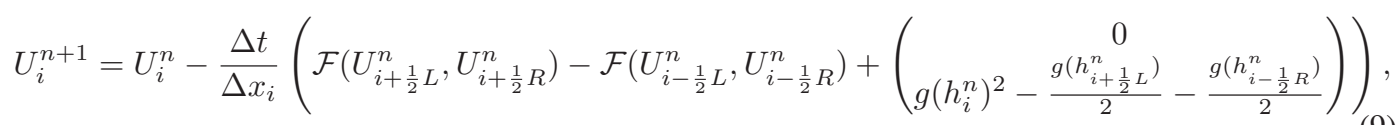

$\mathcal{F}$ merupakan fluks numerik $H L L E$. Isi dari variabel $U_{i+\frac{1}{2} L}^{n}$ dan $U_{i-\frac{1}{2} R}^{n}$ adalah,

$$
\begin{gathered}
U_{i+\frac{1}{2} L}^{n}=\left(h_{i+\frac{1}{2} L}^{n}, h_{i+\frac{1}{2} L}^{n} u_{i}^{n}\right)^{T}, \\
U_{i+\frac{1}{2} R}^{n}=\left(h_{i+\frac{1}{2} R}^{n}, h_{i+\frac{1}{2} R}^{n} u_{i+1}^{n}\right)^{T},
\end{gathered}
$$

dengan nilai tiap variabel juga penggunaan friksi dapat dilihat pada [15].

Fluks numerik HLLE yang digunakan untuk mencari nilai $\mathcal{F}$ dapat dijabarkan sebagai berikut [6].

$$
\mathcal{F}\left(U_{i+\frac{1}{2} L}^{n}, U_{i+\frac{1}{2} R}^{n}\right)=t_{1} F\left(U_{i+\frac{1}{2} R}^{n}\right)+t_{2} F\left(U_{i+\frac{1}{2} L}^{n}\right)-t_{3}\left(U_{i+\frac{1}{2} R}^{n}-U_{i+\frac{1}{2} L}^{n}\right),
$$

dengan nilai $t_{1}, t_{2}$, dan $t_{3}$ dicari dengan,

$$
\begin{gathered}
t_{1}=\frac{\min \left(C_{2}, 0\right)-\min \left(C_{1}, 0\right)}{C_{2}-C_{1}}, \\
t_{2}=1-t_{1}, \\
t_{3}=\frac{C_{2}\left|C_{1}\right|-C_{1}\left|C_{2}\right|}{2\left(C_{2}-C_{1}\right)} .
\end{gathered}
$$

Pencarian nilai $C_{1}$ dan $C_{2}$ dengan menghitung,

$$
\begin{gathered}
C_{1}= \begin{cases}u_{R}-2 \sqrt{g h_{R}} & \text { jika } h_{L}=0, \\
\min \left(u_{L}-\sqrt{g h_{L}}, u_{*}-\sqrt{g h_{*}}\right) & \text { jika } h_{L}>0,\end{cases} \\
C_{2}= \begin{cases}u_{L}+2 \sqrt{g h_{L}} & \text { jika } h_{R}=0, \\
\max \left(u_{R}+\sqrt{g h_{R}}, u_{*}+\sqrt{g h_{*}}\right) & \text { jika } h_{R}>0 .\end{cases}
\end{gathered}
$$

Dan menentukan nilai $u_{*}$ dan $h_{*}$ dengan menghitung,

$$
\begin{aligned}
& u_{*}=\frac{1}{2}\left(u_{L}+u_{R}\right)+\sqrt{g h_{L}}-\sqrt{g h_{R}}, \\
& h_{*}=\frac{1}{g}\left[\frac{1}{2}\left(\sqrt{g h_{L}}+\sqrt{g h_{R}}\right)+\frac{1}{4}\left(u_{L}-u_{R}\right)\right]^{2} \text {. } \\
& \underbrace{u_{i-1}^{n+1} \underbrace{n+1}_{\text {(known) }}}_{\text {(known) }} \underbrace{Z_{i}^{n+1 / 2}}_{Z_{i}^{n}} Q_{i+1}^{n+1}
\end{aligned}
$$

Gambar 4: Stensil semi-implicit pada Exner.

Solusi persamaan Exner dicari setelah solusi dari SWE ditemukan. Teknik splitting berlaku saat HLLE tidak lagi digunakan pada pencarian Exner, melainkan semi-implicit yang digunakan. Hal itu berarti 
A. Utomo et.AL.

Implementasi Skema Collocated...

bahwa pencarian nilai $z_{i}^{n+1}$ selain membutuhkan $\left(z_{i}^{n}\right)$, juga membutuhkan $u^{n+1}$ yang sudah diketahui dari SWE (lihat Gambar 4). Persamaan Exner dapat didiskritisasikan sebagai berikut [14].

$$
z_{i}^{n+1}=z_{i}^{n}-\frac{\Delta t}{(1-\phi) \Delta x}\left(Q_{i+\frac{1}{2}}^{n+1}-Q_{i-\frac{1}{2}}^{n+1}\right),
$$

dengan nilai $Q_{i+\frac{1}{2}}^{n+1}$ dan $Q_{i-\frac{1}{2}}^{n+1}$ digunakan grass formula dari Persamaan (6), yang dapat diubah menjadi,

$$
Q_{i \pm \frac{1}{2}}^{n+1}=A_{g} u_{ \pm \frac{1}{2}}^{n+1}\left|u_{i \pm \frac{1}{2}}^{n+1}\right|^{m-1},
$$

dengan nilai $\mathrm{m}$ dapat dilihat pada Bagian II-B. Lalu nilai $u_{i+\frac{1}{2}}^{n+1}$ dan $u_{i-\frac{1}{2}}^{n+1}$ dicari dengan rata-rata yaitu,

$$
u_{i \pm \frac{1}{2}}^{n+1}=\frac{u_{i \pm 1}^{n+1}+u_{i}^{n+1}}{2} .
$$

Sebagai penutup dari bagian ini, dibuat algoritma dari informasi-informasi yang sudah dijelaskan di atas, pada bagian Algoritma 1. Pencarian nilai menggunakan rata-rata merupakan sebuah tindakan yang dilakukan untuk membuat algoritma menjadi lebih sederhana. Pembuktian bahwa rata-rata dapat digunakan pada pencarian nilai $u_{i+\frac{1}{2}}^{n+1}$ dan $u_{i-\frac{1}{2}}^{n+1}$ akan dibuktikan pada Bagian IV.

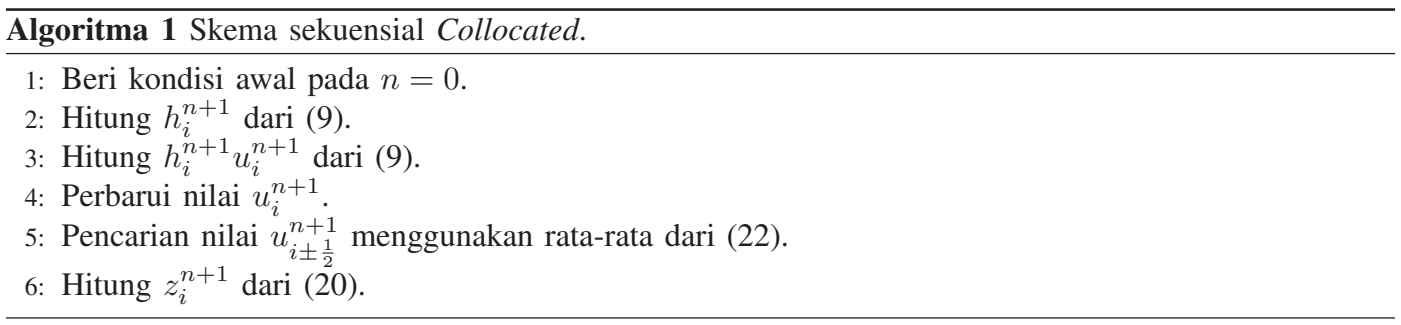

\section{Simulasi NuMERIK}

\section{A. One-dimensional erodible dam break}

Bagian ini diperuntukkan untuk mensimulasikan bendungan runtuh satu dimensi dengan sedimen yang bergerak di bawahnya. Kasus pertama adalah perbandingan antara pemodelan skema dengan solusi acuan. Solusi acuan merupakan solusi yang memiliki titik penghubung atau mesh points yang banyak. Hal ini dilakukan untuk melihat konvergensi dari simulasi. Kasus kedua adalah perbandingan dengan skema staggered pada [14] yang diambil dari literatur [2].

1) Membuktikan konvergensi solusi: ditentukan kondisi awal pada simulasi pada domain $\Omega=[0,1]$ adalah sebagai berikut.

$h_{\text {ini }}(x)= \begin{cases}1 & \text { jika } x \leq 0.5, \\ 0.2 & \text { selainnya }\end{cases}$

Kecepatan awal $u_{i n i}(x)=0$, dan tampilan awal sedimen $z_{i n i}(x)=0$ dengan nilai $m$ pada $Q_{s}$ adalah $m=3, A_{g}=0.005$, dan $\phi=0.1$. Perubahan waktu $\Delta t=\Delta x / 12$. Dilakukan perbandingan dengan solusi acuan. Dapat dilihat dari Gambar 5 bahwa pada waktu $t=0.1$, dapat terlihat bahwa skema menunjukkan hasil simulasi yang mendekati solusi.

2) Perbandingan dengan literatur: perbandingan dengan literatur dilakukan dengan mempelajari sebuah masalah yang diperkenalkan pada [2] dan sudah didemonstrasikan di [14]. Akan dilakukan perbandingan antara skema pada jurnal dengan skema staggered pada [14]. Batas yang digunakan adalah $\Omega=[0,10]$ dengan sebuah bendungan yang diletakkan di tengah-tengah batas. Tinggi di sebelah kiri dam adalah $h_{\text {ini }}(x)=2$ dan di sebelah kanan $h_{\text {ini }}(x)=0.125$. Tinggi sedimen pada awal waktu 

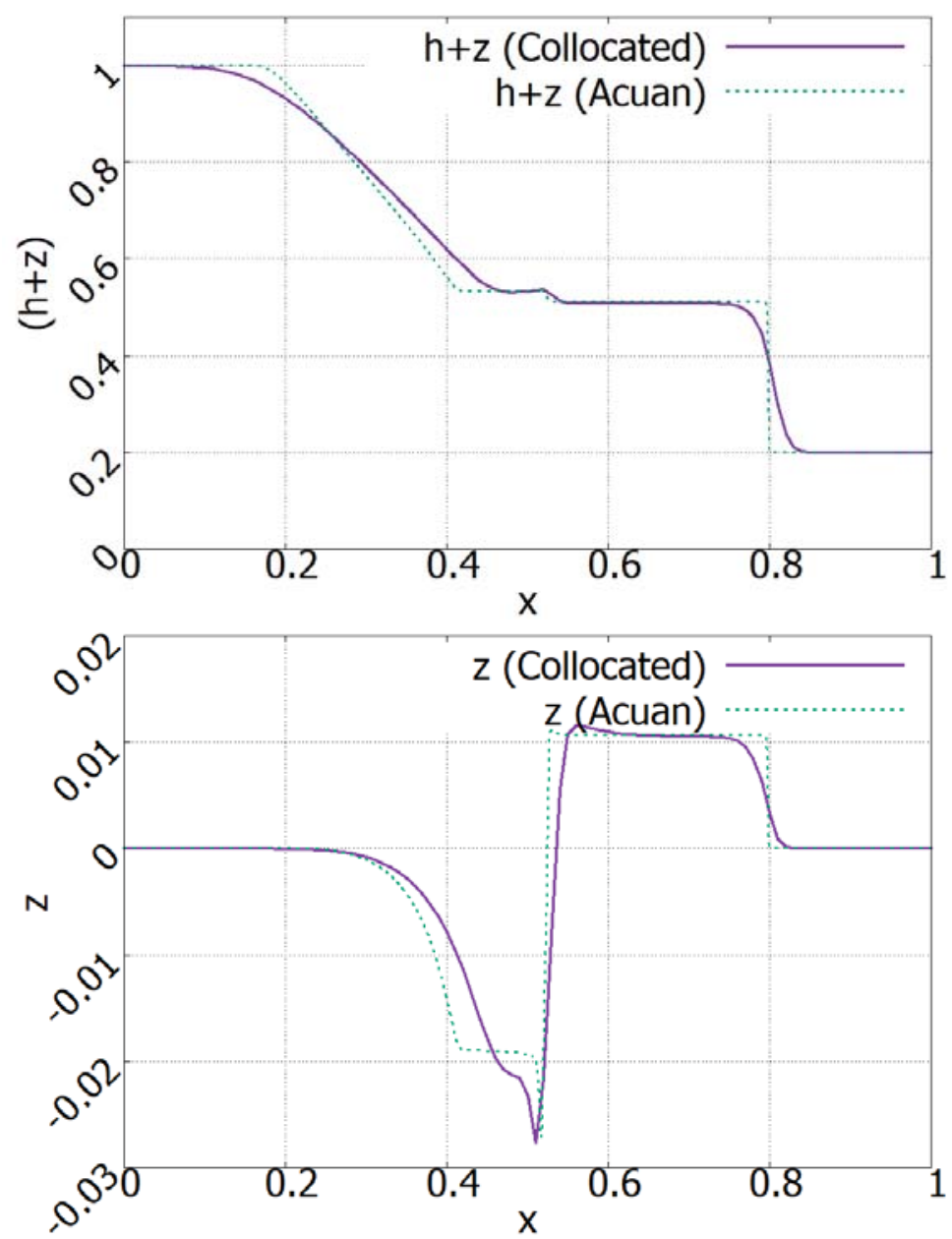

Gambar 5: (a) Permukaan air dan (b) profil sedimen antara skema dengan solusi acuan menggunakan 2000 mesh points).

adalah $z_{\text {ini }}(x)=0, A_{g}=0.005, \phi=0.1, m=3, H=0$, kecepatan fluida $u_{\text {ini }}(x)=0$, dan tidak diberlakukannya friksi. Dipecah dengan kisi sebanyak 400 buah, dan waktu final pada $t_{\text {final }}=1$. Dapat dilihat kecepatan, tinggi air, dan profil sedimen pada Gambar 6 dan 7. Pergerakan yang terjadi sejalan dengan [2].

\section{B. Subcritical steady state over a moveable bump}

Simulasi ini dilakukan dengan kondisi saat adanya sebuah titik di mana tinggi air lebih rendah dari sekitarnya. Perubahan tinggi air untuk mengikuti sekitar memengaruhi sedimen yang ada di bawahnya. Hal ini sudah dibahas di [10] dan juga sudah dibahas di [14]. Setelah itu, dilakukan perbandingan dengan [14].

1) Pembahasan masalah: ditentukan inisiasi awal sebagai berikut.

$(h u)_{\text {ini }}(x)=0.5$,

$z_{\text {ini }}(x)=0.1+0.1 e^{-(x-5)^{2}}$,

$2 g h_{i n i}^{3}(x)+\left(2 g z_{i n i}(x)-12.772\right) h_{i n i}^{2}(x)+0.25=0$. 
A. Utomo et.AL.

Implementasi Skema Collocated...
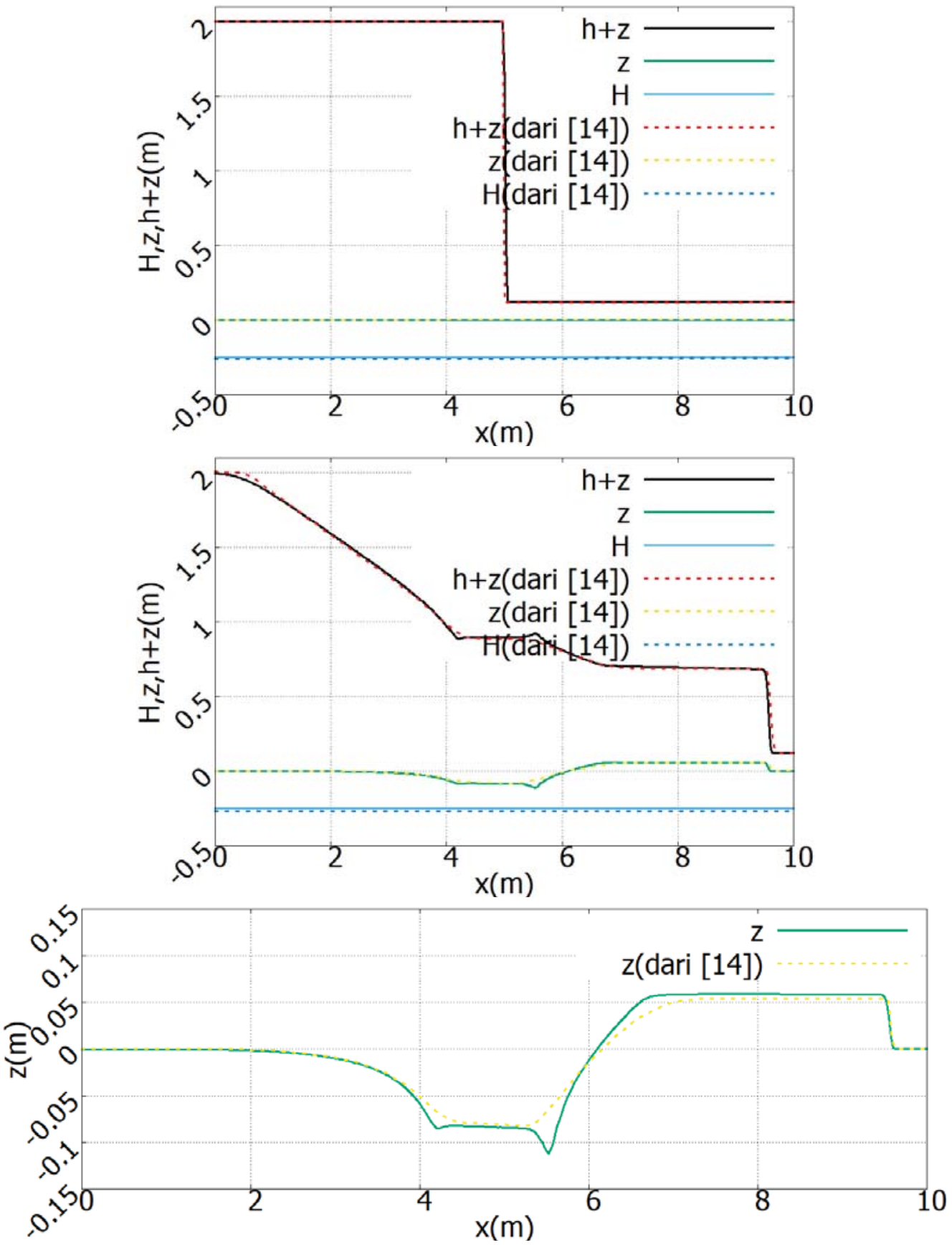

Gambar 6: (a) Kondisi awal bendungan, pada saat $t=0$ dan (b) Kondisi bendungan pada $t=1$, dan (c) pembesaran pada bagian $z$ pada saat $t=1$.

Pencarian nilai $h_{\text {ini }}(x)$ dilakukan menggunakan metode pencarian akar Bisection dengan jarak $a b=$ [0.3 : 0.6]. Pada domain $\Omega=[0: 10]$, inisiasi awal ditunjukkan pada Gambar 8(a). Simulasi dilakukan dengan nilai $A_{g}=0.005, \phi=0.1, H=0$, dan $m=3$. 


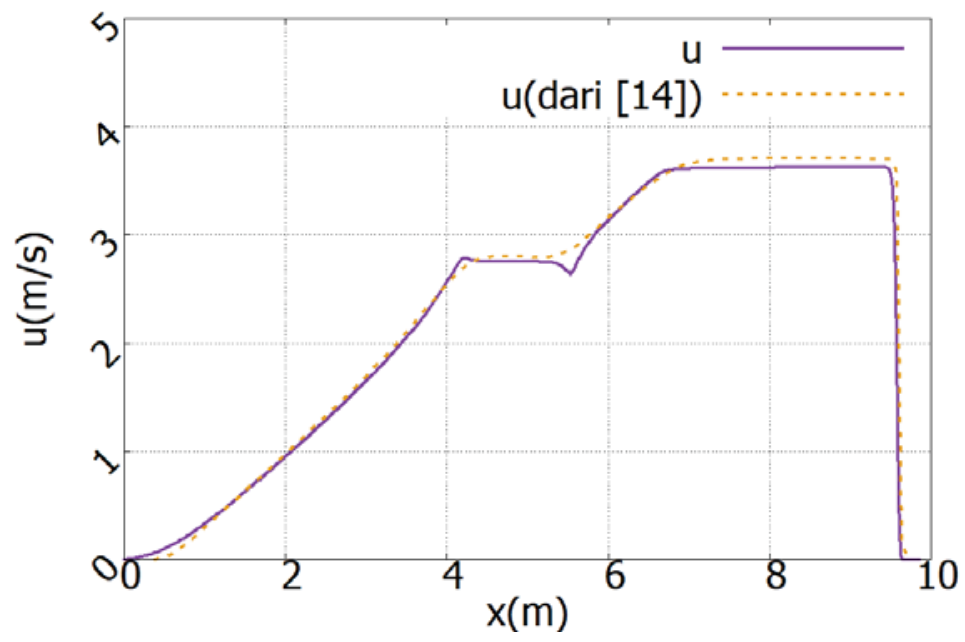

Gambar 7: Profil kecepatan pada simulasi bendungan runtuh. Gambar pada saat $t=1$.
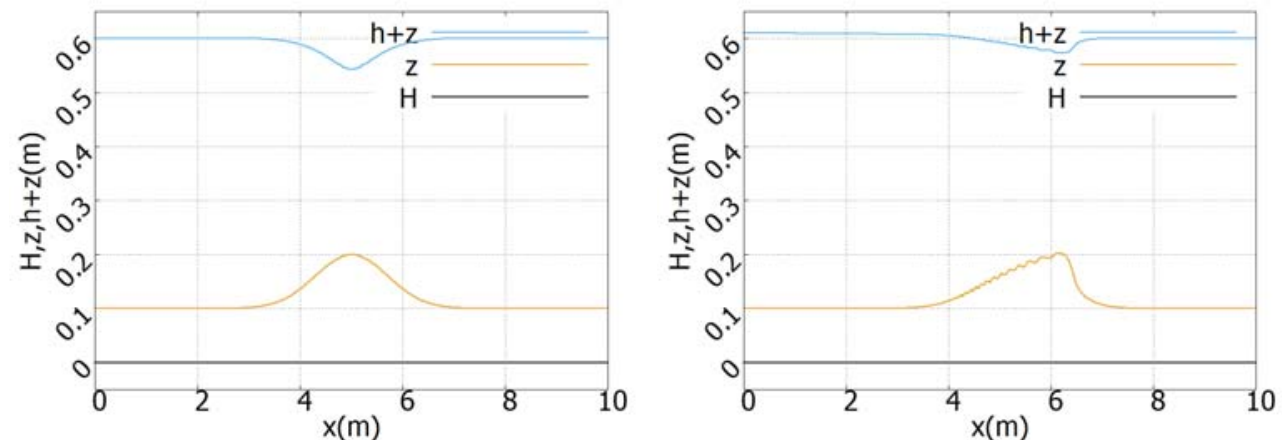

Gambar 8: (a) Profil awal pada saat $t=0$, dan (b) Profil saat $t=1$.

2) Perbandingan: dilakukan perbandingan pada hasil yang ditunjukkan di [14]. Kondisi awal dibuat sama. Dari Gambar 9 terlihat bahwa inisiasi awal terdapat tidak adanya perbedaan antara kedua skema. Selain itu, pada Gambar 9(b) juga terlihat bahwa walaupun ada sedikit perbedaan, namun pergerakan fluida dan sedimen sesuai.

\section{KeSIMPULAN}

Skema baru untuk menghampiri SWE - Exner dikerjakan. Skema pada jurnal ini menjelaskan mengenai teknik splitting, di mana HLLE digunakan dalam pemodelan SWE, dan Exner dengan metode semiimplicit. Pencarian nilai $z_{i}^{n+1}$ pada Exner dilakukan dengan menggunakan rata-rata nilai $u^{n+1}$ dari $S W E$. Hasil dari jurnal yang dapat dilihat pada Bagian IV menunjukkan bahwa skema collocated yang dibentuk sesuai dengan skema literatur dari [2] dan juga skema subcritical steady state over a moveable bump di [14]. Skema yang dibentuk pada jurnal ini juga konvergen terhadap solusi acuan.

\section{PUSTAKA}

[1] Christophe Ancey. Stochastic modeling in sediment dynamics: Exner equation for planar bed incipient bed load transport conditions. Journal of Geophysical Research: Earth Surface, 115(F2), 2010. 
A. Utomo et.AL.

Implementasi Skema Collocated...
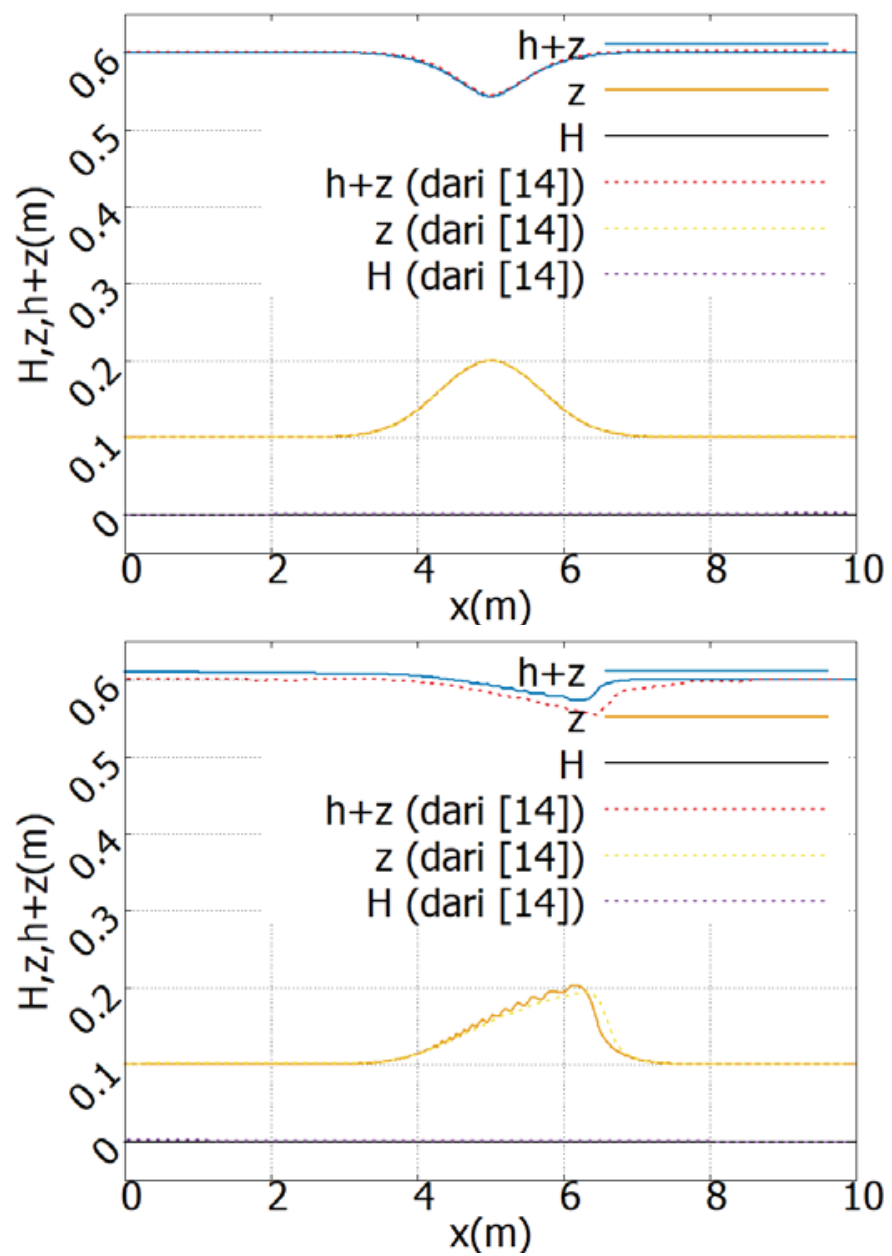

Gambar 9: (a) Perbandingan pada $t=0$, dan (b) Perbandingan saat $t=1$ dengan menggunakan $A_{g}=0.005$ dan $m=3$.

[2] Emmanuel Audusse, Christophe Berthon, Christophe Chalons, Olivier Delestre, Nicole Goutal, Magali Jodeau, Jacques SainteMarie, Jan Giesselmann, and Georges Sadaka. Sediment transport modelling: Relaxation schemes for saint-venant-exner and three layer models. In ESAIM: proceedings, volume 38, pages 78-98. EDP Sciences, 2012.

[3] Emmanuel Audusse and Marie-Odile Bristeau. Finite-volume solvers for a multilayer saint-venant system. International Journal of Applied Mathematics and Computer Science, 17(3):311-320, 2007.

[4] Christophe Berthon, Stéphane Cordier, Olivier Delestre, and Minh Hoang Le. An analytical solution of the shallow water system coupled to the exner equation. Comptes Rendus Mathematique, 350(3):183-186, 2012.

[5] Christophe Berthon and Fabien Marche. A positive preserving high order vfroe scheme for shallow water equations: a class of relaxation schemes. SIAM Journal on Scientific Computing, 30(5):2587-2612, 2008.

[6] Francois Bouchut. Nonliniear Stability of Finite Volume Methods for Hyperbolic Conservation Laws and Well-Balanced Schemes for Sources. Birkhauser, 2000.

[7] François Bouchut, Julien Le Sommer, and Vladimir Zeitlin. Frontal geostrophic adjustment and nonlinear wave phenomena in one-dimensional rotating shallow water. part 2. high-resolution numerical simulations. Journal of Fluid Mechanics, 514:35-63, 2004.

[8] Zhixian Cao, Gareth Pender, and Jian Meng. Explicit formulation of the shields diagram for incipient motion of sediment. Journal of Hydraulic Engineering, 132(10):1097-1099, 2006

[9] SE Coleman and VI Nikora. Exner equation: A continuum approximation of a discrete granular system. Water Resources Research, 45(9), 2009.

[10] Stéphane Cordier, Minh H Le, and T Morales De Luna. Bedload transport in shallow water models: Why splitting (may) fail, how hyperbolicity (can) help. Advances in Water Resources, 34(8):980-989, 2011.

[11] Olivier Delestre, Stéphane Cordier, Frédéric Darboux, and Francois James. A limitation of the hydrostatic reconstruction technique for shallow water equations. Comptes Rendus Mathematique, 350(13-14):677-681, 2012. 
[12] MJ Castro Díaz, Enrique D Fernández-Nieto, and AM Ferreiro. Sediment transport models in shallow water equations and numerical approach by high order finite volume methods. Computers \& Fluids, 37(3):299-316, 2008.

[13] Putu Harry Gunawan. Numerical simulation of tsunami hazard mitigation by mangrove forest in north coast bali, indonesia. Jurnal Matematika, 5(1):1-13, 2015.

[14] Putu Harry Gunawan, R Eymard, and SR Pudjaprasetya. Staggered scheme for the exner-shallow water equations. Computational Geosciences, 19(6):1197-1206, 2015.

[15] Putu Harry Gunawan and Xavier Lhébrard. Hydrostatic relaxation scheme for the 1d shallow water-exner equations in bedload transport. Computers \& Fluids, 121:44-50, 2015.

[16] Robert H Kadlec. Overland flow in wetlands: vegetation resistance. Journal of Hydraulic Engineering, 116(5):691-706, 1990.

[17] John Nicholas Newman and John Grue. Marine hydrodynamics. MIT press, 2018.

[18] Guy Simpson and Sébastien Castelltort. Coupled model of surface water flow, sediment transport and morphological evolution. Computers \& Geosciences, 32(10):1600-1614, 2006. 
